\title{
Türkiye'de Paranın Depolitizasyonu, Merkez Bankası Bağımsızlığı ve Siyasal Partilerin Dönüşümü ${ }^{1}$
}

\author{
Ragıp YILMAZ² - Oytun MEÇiK
}

Başvuru Tarihi: 23.09.2021 Kabul Tarihi: 20.10.2021 Makale Türü: Araştırma Makalesi

\section{Öz}

Neoliberalizm, para politikasının siyasetten bağımsız, teknokrasinin ilkeleri etrafında uzmanlık ve bilimselliğin öne çıktı̆̆ı bağımsız merkez bankaları tarafından gerçekleştirilmesini desteklemektedir. Bu çalışma merkez bankası bağımsızlğııı, neoliberal düşünce ve teknokrasiye uyum bağlamında Türkiye'deki siyasal partilerin desteği açısından incelemektedir. Neoliberal düşüncenin Türkiye'de tam anlamıyla yerleştiği 2001 yllındaki Güçlü Ekonomiye Geçiş Programı öncesi ve sonrasında, siyasal partilerin merkez bankası bağımsızlı̆̆ı konusunda tercihlerini belirlemek amacıyla 1999 ve 2002 yillarında siyasal partilerin ilan ettikleri seçim beyannameleri analiz materyali olarak seçilmiştir. Seçim beyannamelerinde yer alan merkez bankası bağımsızlğı̆ıa ilişkin ifadeler eleştirel söylem analizi yöntemiyle çözümlenmiştir. Bulgular, farklı ideolojilere sahip ve siyasetin farklı kanadında bulunan partilerin enflasyonu düşürmek, kamu açıkların azaltmak ve siyasetin müdahalesini engellemek amaçlarıyla para politikasında bă̆ımsız merkez bankasını desteklediğini ve seçmenlerine ilan ettiğini göstermektedir. Sonuç olarak, siyasal partiler neoliberal düşünceye uyum sağlamışlar ve merkez bankası bağımsızlı̆̆ın kendi ideolojilerine ve seçmenlerin tercihlerine uygun olmasa da desteklemişlerdir. Her bir siyasi parti ekonomide kendi ideolojisini terk etmiş ve her biri neoliberal bir siyasal organa dönüşmüş̧ür. Para politikası da teknokrasinin egemenliğinde bilimsellik ve uzmanlık ilkeleri bağlamında toplumsal sorunlar karşısında nötr bir kimliğe kavuşmuştur.

Anahtar Kelimeler: Neoliberalizm, Teknokrasi, Merkez Bankası Bağımsızlığı, Eleștirel Söylem Analizi

Atıf: Yılmaz, R. ve Meçik, O. (2021). Türkiye’de paranın depolitizasyonu, merkez bankası bağımsızlı̆ı ve siyasal partilerin dönüşümü. Anadolu Üniversitesi Sosyal Bilimler Dergisi, 21(4), 931-952.

\footnotetext{
${ }^{1}$ Bu çalışma etik kurul izin belgesi gerektirmemektedir.

2 Eskişehir Osmangazi Üniversitesi İktisadi ve İdari Bilimler Fakültesi Uluslararası İlişkiler Bölümü, r.yilmaz@ogu.edu.tr, ORCID: 0000-0002-15226542

${ }^{3}$ Eskişehir Osmangazi Üniversitesi İktisadi ve İdari Bilimler Fakültesi İktisat Bölümü, oytunm@ogu.edu.tr, ORCID: 0000-0002-7409-6266
} 


\title{
Depoliticization of Money, Central Bank Independence and Transformation of Political Parties in Turkey
}

\author{
Ragıp YILMAZ ${ }^{4}$ - Oytun MEÇiא 5
}

Submitted by: 23.09 .2021

Accepted by: 20.10 .2021

Article Type: Research Article

\begin{abstract}
Neoliberalism supports the realization of monetary policy by independent central banks, which are independent of politics, where expertise and science come to the fore around the principles of technocracy. In this study, central bank independence is examined in terms of support of political parties in the context of adaptation to neoliberalism and technocracy in Turkey. Neoliberalism in Turkey is completely settled with the "Transition to Strong Economy Program" in 2001. Before and after this program, election statements announced in 1999 and 2002 by political parties were selected as the analysis of the material in order to determine the preferences of political parties regarding central bank independence. Statements regarding central bank independence in the election statements were analyzed using the Critical Discourse Analysis method. The findings show that parties with different ideologies and different wings of politics support the independent central bank in monetary policy and announced it to their voters for the purposes of price stability, lowering inflation, reducing public deficits, and preventing the intervention of politics. As a result, political parties have adapted to neoliberalism and supported central bank independence, even if it was incompatible with their ideology and voters' preferences. Each political party has abandoned its own ideology in the economy, and each has turned into a neoliberal political institution. Under the rule of technocracy, monetary policy has gained a neutral identity in the face of social problems in the context of scientific and expertise principles.
\end{abstract}

Keywords: Neoliberalism, Technocracy, Central Bank Independence, Critical Discourse Analysis

\footnotetext{
4 Eskişehir Osmangazi University Faculty of Economics and Administrative Sciences Department of International Relations, r.yilmaz@ogu.edu.tr, ORCID: 0000-0002-1522-6542

${ }^{5}$ Eskişehir Osmangazi University Faculty of Economics and Administrative Sciences Department of Economics, oytunm@ogu.edu.tr, ORCID: 0000-0002-7409-6266
} 


\section{Giriş}

Dünya ekonomisi, kapitalizmin “Altın Çağı” olarak ifade edilen Keynesyen Refah Devleti döneminden, bugünün dünyasında egemenliğini tesis eden neoliberal düşüncenin hâkim olduğu döneme ilerlerken ekonomik, siyasal ve toplumsal yapıları da içeren yapısal değişimler geçirmiştir. Bu değişim süreci, ekonomi politikasında Keynesyen dönemde var olan doğruların yerine bambaşka tercihlerin geçmesini beraberinde getirmiştir. Keynesyen dönemde birincil makroekonomik sorun olarak ele alınan işsizlik yerine, monetarizm ve rasyonel bekleyişler hipotezi teorilerindeki yaklaşımları temel alan neoliberalizm, enflasyon sorununu öne çıartmıştır. Enflasyon sorununu çözmek amacıyla enflasyon hedeflemesi ve merkez bankası bağımsızlığı bütün ülkelere tavsiye edilmiştir. Böylece para politikası toplumsal sorunlar bakımından gözden uzak tutulmuş ve siyasetin etkin olmadığı bir para politikası uygulamaya konulmuştur. Para politikası siyasal ve toplumsal etkenlerden uzaklaşarak, teknokrasiye devredilmiş, bilimsellik ve uzmanlık ilkeleri çerçevesinde piyasanın tercihleri doğrultusunda yönetilmeye başlanmıştır.

Teknokrasiyi öne çıaran neoliberalizm; birey, piyasa ve devlete ilişkin tarihsel, toplumsal veya kültürel herhangi bir bağlama yer vermeyen boşluklara sahiptir. $\mathrm{Bu}$ soyut tasvirlere dayalı boşluk tabula rasa ${ }^{6}$ kavramıyla karşılanır. Neoliberalizmin ontolojik ön kabulünün en önemli açmazı belirli bir tarihsel, toplumsal veya kültürel bağlamı hesaba katmamasıdır. Yani bir tür tabula rasa durumunun örtük olarak varsayılmasıdır (Evre, 2015, s. 4-5).

Küreselleşme sürecinde giderek belirginleşen neoliberalizm, beraberinde uluslararası sermaye hareketlerini getirmektedir. 19. ve 20. yüzyıl küreselleşme evrelerinin sermaye hareketleri açısından en önemli fark1, birincisinin reel bir mal ile -altın standardında- düzenlenirken, günümüzdeki ikinci evrenin fiyat paraların nominal değişim hareketlerine dayalı olmasıdır. Bu mekanizma, ulusal paraların değişim hadlerini belirsizleştirir. Bu belirsizlik, finansal sermayenin akışkanlığını, reel üretim dünyasından koparmıştır (Yeldan, 2013, s. 19). Böylece para, bir meta olarak önem yitirmiş ancak bir değer olarak yükseliş yaşamıştır (Simmel, 2011, s. 204-218).

Modern ekonominin küresel eğilimler çerçevesinde finansallaşmasına; liberalleşme, merkezsizleşme ve eşitsizliğin derinleşerek yoğunlaşma eğilimi gibi gelişmeler eşlik etmektedir. Devletin üretim çekirdeğinden uzak bir noktaya taşınması ve sosyal risklerin yönetilmesi gerekliliği, merkez bankası gibi organizasyonların politika inşa süreçleri, pratikler ve ideolojiler bağlamında toplumsal dokuya yaslandığı yapılar tasarlanması ihtiyacını öne almaktadır (Gökgöz, 2013, s. 19).

$\mathrm{Bu}$ çalışma, neoliberalizm ile gündeme gelen teknokrasi ve siyaset arasındaki etkileşimi, Türkiye'de uygulamaya konulan Güçlü Ekonomiye Geçiş Programı (GEGP) öncesi ve sonrasındaki dönemde, iktidarda tek başına ya da koalisyon ortağı olarak bulunmuş ve ana muhalefet rolüne sahip siyasal partilerin seçim beyannameleri bağlamında analiz etmektedir. Çalışmada siyasi partilerin yaklaşımlarını değerlendirmek amacıyla eleştirel söylem analiz (ESA) yöntemi kullanılmıştır. Seçim beyannamelerinde ele alınan siyasal partilerin merkez bankası bağımsızlığına yönelik söylemleri değerlendirilerek neoliberalizm ve teknokrasiye uyumları analiz edilmiştir. Çalışmanın Türkiye'de teknokratik yönetimin yerleşmesi bağlamında neoliberal düşüncenin MB bağımsızlığı aracılığıyla farklı ideolojilere sahip partilerin egemen yapıya uyum sağlamada nasıl bir dil kullandıklarının belirlenmesi açısından literatüre katkı yapması beklenmektedir.

\section{Neoliberalizm ve Teknokratik Siyaset}

Dünya ekonomisinde yaşanan krizler ve bu krizlerin ardından uygulamaya konulan ekonomi politikaları, daha önceki dönemden farklı teori/düşüncelere dayalı şekilde ekonomi politikalarını yönlendirmiştir. Krizler, sadece ekonomik hayatı etkilemekle kalmamış, bunun yanı sıra siyasal yapıları, ideolojileri, toplumsal

\footnotetext{
${ }^{6}$ Kavram, empirist filozof Locke (2000) tarafından epistemolojik bağlamda, insan zihninin “boş levha”ya benzetildiği metaforik anlamda kullanılır.
} 
aktörlerin tercihlerini ve devletleri, kurumlarını dönüştürmeye ya da dönüşüme zorlamıştır. Özellikle devletlerin dönüşüm geçirerek, kriz sonrasında ortaya çıan uluslararası sisteme uyma çabaları, siyasal ve toplumsal aktörlerin davranış ve tercihlerini de etkilemiştir. Siyasal ve toplumsal aktörler verecekleri desteklerle, kurumsal düzenlemeler içine doğrudan/dolaylı müdahil olarak, kurumların değişebilmesinin ve süreklilik kazanabilmesinin önünü açmıştır (Haggard \& Kaufmann, 1995, s. 7). Sermaye hareketlerinin kontrol edildiği ve sabit döviz kuru sistemine dayalı Bretton Woods sisteminin çöktüğü (Garrett, 1998, s. 797) Keynesyen Refah Devleti yerine, toplumun refahını önceleyen vergi ve kamu harcamalarına yönelik politikaların kısıtlandığı, para ve maliye politikalarının piyasa şartlarına göre düzenlendiği, toplumsal sorunları ikincil plana atan neoliberal yapılanma böylece hâkim kılınmıştır (Centeno \& Cohen, 2010). 1929 Buhranı sonrasında planlı ekonomiye dayalı ve bürokrasinin yönetiminde egemen olduğu (Keyder, 2009, s. 11-12) ekonomik sistemin yerine gelen neoliberalizmin en dikkat çekici özelliği, bilimselliğe dayalı ve uzmanların egemen olduğu evrensellik vurgusu altında, politikaların teknokrat niteliğine vurgu yapmasıdır (Centeno, 1993, s. 307-308). Dünyanın her ülkesinde kabul gören neoliberalizm bu haliyle adeta kendi küreselleşmesini yaratmıştır (Duménil ve Lévy, 2005, s. 10).

Kendi küreselleşmesini yaratan neoliberalizmde teknokratik yönetimler meşruiyetlerini, kurumlara atanan yöneticilerin hâkim teorinin doğrularının savunucusu ve uygulayıcısı olmalarıyla sağlamıştır. Demokratik süreçlerin etkinliğini azaltan teknokrat yönetim anlayışı, monetarizmin (Friedman, 1963) ve rasyonel bekleyişler hipotezinin (Muth, 1961; Sargent \& Wallace, 1975) desteklediği neoliberalizmi dayanak kabul ederek (Amable, 2011), kendi oluşturduğu demokratik meşruiyeti sağlamaya çalışmıştır (Garrett, 1998, s. 788). Zira teknokrasi, liberal demokrasinin normatif ideolojisinden sapan bir düzen tasavvur ettiğinden (Kiely, 2017; Gaus, Landwehr \& Schmalz-Bruns, 2020, s. 337) siyasal partilerin ağırlıkta olduğu bir demokrasi anlayışına karşı çıkmıştır (Bickerton ve Accetti, 2017, s. 201). Bunun yerine teknokrasi, teknik bilgi ve uzmanlık yoluyla toplumun yararına olan davranışlara meşruiyet kazandıran, toplumsal sorunlara bağımsız tanımlama ve uygulamalarla objektif çözümler amaçlayan bir temsil ilkesi olarak tanımlanmıştır (Habermas, 2015). Buna uygun şekilde, teknokrasi, ekonomi politikasında siyasal partilerin etkinliğini azaltan bilimsel bir yaklaşımı ve elit yöneticileri inşa etme süreci olarak tasarlanmıştır (Bertsou \& Caramani, 2019).

Siyasetin ekonomi politikalarından uzaklaştırılmasındaki temel saik ise siyasal partilerin seçim kazançlarına odaklanarak toplumun sorunlarına temas etme yeteneklerini kaybetmeleridir (Caramani, 2017, s. 54). Bunun önüne geçebilmek için bilim ve uzmanlık, hükümetlerin ve siyasal partilerin karar alma mekanizmalarının temeline yerleştirilmelidir. Böylece teknik ile siyaset yer değiştirir ve teknokratların rolü siyaset dışı kavramlarla tanımlanır (Putnam, 1977), hükümetlerin ekonomiye müdahale etmesinin önüne geçilir ve toplumsal hareketleri engelleyebilmek için ekonomi politikaları ve yönetimi teknokratlaştırılır (Kiely, 2017, s. 737). Diğer bir ifadeyle siyasal güç ve karar verme otoritesi, siyasetçilerden ekonomik uzmanlara kaydırılır (Christensen veMandelkern, 2021, s. 2; Chwieroth, 2007). Siyasal karar alma mekanizmaları depolitize edilir ve demokratik süreçlerden yalıtılır (Sanchez-Cuenca, 2017, s. 362; Sönmez, 2011, s. 43). Bu süreç, dünya ekonomisinde paradigma değişimini (Kuhn, 2008, s. 282) hızlandırır ve o güne kadar var olan inançları, değerleri ve ideolojileri teknokrasinin egemenliğine doğru yönlendirir (Centeno, 1993).

Serbest piyasayı destekleyen neoliberal düzenin tesisinde her ne kadar siyaset dışlansa da kendinden önceki liberal düzende olduğu gibi devlet desteği gereksinimi söz konusudur (Polanyi, 2006). Hatta bu süreçte devlet, gölge bir niteliğe bürünüp, sivil toplum ve şirketlerle iş birliği içine girmiş (Cohen, 1977; Arrighi, 1990; Cerny, 1997, s. 270; Evans, 1997), yeni düzenin gereklerine göre kurumsal dönüşüm gerçekleştirmiş (Wallerstein, 2005), birincil aktör olarak hareket etmeye başlamış (Meyer, Boli, Thomas \& Ramirez, 1997) ve yeni düzene uyumda zorlayıcı devlet işlevini yerine getirmiştir (Garrett \& Lange, 1995; Simmons, Dobbin \& Garrett, 2006; Harvey, 2015). Böylece ülkelerde uzmanlar/teknokratlar demokrasisi egemen hale getirilirken (Freeman, 2002), bir yönüyle ulus-devlet öncesinde yönetim yapısında hakimiyet tesis etmiş olan ulema yönetimi yeniden güç kazanmıştır (Gellner, 1992). 
Siyasal etkenlerin ekonomi yönetiminden uzaklaştırılıp teknokratik bir yapıya kavuşturulması siyasal mücadele amaçlarında da değişim yapmıştır. Keynesyen Refah Devleti döneminde sınıf temelli olan siyasal partiler arasındaki iktidar mücadelesini çıkar temelli bir mücadeleye dönüşmüştür (Hall, 2010). Dolayısıyla emek önemini kaybedip, iş̧̧iler birer müşteri olarak değerlendirilmeye başlanmıştır (Boyer, 2013, s. 5-6). Neoliberal dönemde sınıf temelli politikaların terk edilmesi ve çıar temelli politikalara doğru yönelim, toplumsal sorunları ikinci plana atan ve enflasyona odaklanan para politikasına öncelik vermiştir (Centeno \& Cohen, 2012, s. 319). Özellikle gelecekteki belirsizliği azaltıp zaman tutarsızlı̆̆ı problemine çözüm bulmak (Kydland \& Prescott, 1977; Barro \& Gordon, 1983a; Barro \& Gordon, 1983b) ve bu sayede uluslararas1 piyasalarda kredibilite kazanma uğraşısı içine girilmiştir (Forder, 2004; Tavlas, 1993, s. 676). Ekonomi yönetiminde, yönetişim ekonomisi (Sönmez, 2011; Bayramoğlu, 2010) bağlamında, paranın yönetimi, egemen hale gelen, hükümetin müdahale edemediği teknostrüktürel yapılara (Galbraith, 1971, 2002; Christensen \& Madelkern, 2021), enflasyonu hedefleyen bağımsız merkez bankalarına (Goodfriend, 2007, s. 48) terk edilmiştir. Böylece imkânsız üçleme probleminden (Mundell, 1962, 1963, 1964) uzaklaşılırken; demokrasi, ulusal bağımsızlık ve küreselleşme tercihlerinden oluşan başka bir üçleme (Rodrik, 2011) kendisini siyasal ve toplumsal alanda benimsetmeye başlamıştır.

Ekonomi yönetiminin teknokratlaşması, teknokrasinin objektif gerekliliklerinin siyasal yapılara dayalı modelin yerine geçmesine yol açarken, bu durum siyasetin ve siyasal partilerin bilimselleşmesine ve siyasal düşüncelerden uzaklaşan, otoriter siyasal yapıların siyasette hâkim olmasını sağlar (McCarthy, 1978, s. 12). Böylece tek bir ideolojinin önerdiği ekonomi politikaları bütün siyasal partilerin ortak doğrusuna dönüşür. Tek doğru anlayışının birbirinden farklı ideolojilere sahip siyasal partiler tarafından kabul görmesinin temel sebebi, bilimsel ya da teknik rasyonalitenin değer yargılarından bağımsız olmasıdır. Ayrıca benimsenen ideolojinin teorilerine dayalı ekonomi politikasındaki uygulamalar, tamamıla toplumsal yapıdaki güç anlayışından ayrışır (Centeno, 1993, s. 318). Para ve para politikasının bağımsız merkez bankaları yoluyla teknokrasiye birakılması, enflasyonu kontrol ederek ve sermaye hareketleri yoluyla küresel piyasalara uyumu ve kredibilite sorununu çözebilmektedir. Bunun sonucunda ülkede toplumsal sorunların çözümü ikinci planda kalarak, demokratik katılım ve siyasal çözümler konusunda sorunların çıkmasına yol açabilmektedir.

\section{Merkez Bankası Bağımsızlığı ve Siyasal Dönüşüm}

Neoliberal düşüncenin öne sürdüğü siyasetten arındırılmış merkez bankası düşüncesinin, enflasyonu düşürmede ve kontrol altına almada önemli bir role sahip olduğu ileri sürülmektedir. Merkez bankalarının bağımsızlığına vurgu yapılırken kredibilite kazanılması (Rogoff, 1985), para politikasında hükümetlerin etkisinin sınırlandırılarak enflasyonun düşürülmesi (Alesina, 1988; Grilli, Masciandaro \& Tabellini, 1991; Cukierman, 1992; Cukierman, Webb \& Neyapti, 1992; Eijffinger \& de Haan, 1996; Crowe \& Meade, 2008; Brumm, 2011) ve hükümetlerin maliye politikalarında sınırlandırılması öne çıkarılır (Berument \& Neyaptı, 1999; Crowe \& Meade, 2007: 70; Bodea \& Higashijima, 2017). Bunun yanı sira finansal piyasaların küreselleşmesiyle birlikte uluslararası piyasalardan kredibilite kazanarak ödemeler dengesinde istikrarı sağlamak, geleceğe yönelik beklentileri uyumlaştırılmak, iktidarda kalma sürelerini uzatabilmek ve uluslararası finansal işlemlerde kendi ülkelerinin kısıtlamalarını azaltabilmek amaçları da merkez bankalarının bağımsızlaştırılmasında etkili olur (Maxfield, 1997, s. 4; Snowdon \& Vane, 2012). Ülke içinde ise refah yaratmak, gelecekteki hükümetleri sınırlandırmak, politika yapabilme kapasitesini artırmak, seçim fırsatçılığını engellemek ve hükümetlerin partizanlıklarını sınırlandırmak için politikacılar merkez bankası bağımsızlığına karar verir (Bernhard, Broz \& Clark, 2002, s. 19). Diğer yandan bağımsız merkez bankası tercihi parasal taahhüt mekanizmasını devreye sokacağından, siyasal partilere, çeşitli baskı gruplarının çıkarlarını, siyasal etkinliğin yeniden düzenlenmesini ve nihayetinde iktidarda kalabilme sürelerini yönetebilme firsatı verir (Bernhard \& Leblang, 2002). Bunların sonucunda merkez bankası bağımsızlı̆̆ı, parayı basan otorite ile parayı harcayan otorite arasında bölünme anlamına gelir (Özatay, 2011, s. 319; Agoba, Abor, Osei \& Sa-Audu, 2017). 
Otoritenin paylaşıldığı bağımsız merkez bankası, para politikasını fiyat istikrarı amacı doğrultusunda yönetir (Cukierman, 1994a). Enflasyonu kontrol etmeye yönelik para politikaları, teknokrasinin elinde bilimsellik ve uzmanlık ölçütlerine göre yönetilir. Tıpkı parasal birliklerde olduğu gibi ulusal para politikaları kural temelli belirlenir. Böylece iktidarda kalmak arzusuyla hareket eden, seçim kazanmayı temel amaç olarak gören siyasetçilerin önüne geçilir. Ellerine geçirdikleri yasal yetkilerle Phillips eğrisinde yapmaya çalışacakları manipülasyonlar engellenir. Böylece rasyonel olmayan seçmen varsayımı altında, teknokrat olan merkez bankası yöneticileri, siyasetçilerin seçim öncesinde genişletici para politikası tercihlerinin önüne geçer (Nordhaus, 1975; Alesina \& Gatti, 1995; Lohmann, 1998, s. 403). Bununla birlikte, zaman tutarsızlığ1 problemini önüne geçmeye çalışılırken ülkedeki güçlü baskı gruplarının siyasal sonuçlar üzerinde etkili olabilmeleri, teknokrat bürokratlar ve onların yönettiği merkez bankası tarafından engellenir (Alesina \& Tabellini, 2008). Böylece para politikaları, neoliberalizmin öngördüğü şekilde sadece fiyat istikrarını hedefler, işsizlik gibi sosyal sorunları ikinci plana atar (Alesina \& Stella, 2010). Bu tercih, enflasyon ve istihdamı birbirlerinin alternatif maliyeti haline getirir. Bunun sonucunda siyasal partiler ve sendikalar pasifleşir (Cukierman \& Lippi, 2001).

Siyaseti ve toplumsal grupları para politikasının dışında tutma amaçlarına varma yolunda bağımsız merkez bankalarının para politikalarında etkin olabilmeleri ve siyasal müdahalelerden tam anlamıla uzak kalabilmeleri için yasal yönden desteklenmeleri gerekir. Yasalarla desteklenen bağımsızlığın en önemli göstergesi banka yönetiminin görev süresinin ve yöneticilerin atanmasında siyasal karar mekanizmalarının dışarıda bırakılmasıdır. Ancak mevzuat ve uygulama arasında farklılık olmaması gerekir. Bu tür bir farklılık olması bankanın bağımsızlığını zorlaştırmaktadır (Cukierman, 1994a, s. 1439). Uygulama ve yasal mevzuat arasında farklılığın olmaması için ülkede hukukun üstünlüğü anlayışının tam yerleşmesi gerekmektedir (Klomp \& de Hann, 2010; de Haan, Bodea, Hicks \& Eijffinger, 2018, s. 186-187).

Merkez bankası bağımsızlığı, ülkede siyasal ve ekonomik istikrarın yerleştirilmesinde en önemli araç olarak değerlendirilir. Ülkede hükümetlerin iktidarda kalma süresi ve siyasal istikrarsızlığı gösteren parti politik istikrarsızlığı ve merkez bankası bağımsızlığı arasında pozitif yönlü bir ilişki mevcuttur (Cukierman, 1994a). Demokratik siyasal sistemlerde farklı ideolojiler etrafında siyaset yapan siyasal partiler iktidar mücadelesine girer ve hükümetlerin değişim sıklığı da bu mücadeleyi içerir. Bir ülkede siyasal istikrarsızlık yüksek olduğunda iktidara gelen parti, iktidarda kalma süresinin kısa olduğunu bilir ve gelecekteki seçimleri kaybetme ihtimalinin yüksek olduğunun farkındadır. Bundan dolayı muhalefette olan partinin iktidara geldiği zaman, para politikasını kendi amaçları doğrultusunda kullanmasını engellemek için bağımsız bir merkez bankasını tercih eder. Siyasal istikrarsızlığın artması, partilerin iktidarda kalma süresini kısaltır ve bağımsız merkez bankası politikalarına yol açar (Bagheri \& Habibi, 1998, s. 189). Para politikalarının bağımsız merkez bankalarına atanan teknokratların elinde olması, siyasal çatışmaların maliyetlerini azaltır (Keefer \& Stasavage, 2002; Crowe, 2008).

Siyasal partilerin ideolojileri de merkez bankası bağımsızlığı yaklaşımında etkilidir. Merkez sol partiler, istihdama yönelik politikalara enflasyondan daha fazla önem verir ve sermayenin vergilendirilmesini tercih ederler. Sağ partiler ise enflasyona odaklanıp, istihdam yaratma politikalarını ikinci plana atarlar. Ayrıca sermayenin güçlenmesini ve özel sektöre dayalı sermaye birikiminin önünü açmayı hedeflerler (Hibbs, 1977). Ancak son dönemlerde merkez sol partilerin taahhüt mekanizmasını işleten merkez bankası bağımsızlığına destek vermeye başladıkları da görülür (Garrett, 1995). Sol partilerin bu tercihinde etkili olan en önemli faktör, küresel piyasalardaki değişimlerle birlikte ülkelerin istihdam yapısının değişmesidir. İmalat sanayinin istihdamında gerileme, hizmetler sektörünün genişlemesi, kamu sektöründe istihdamın artması ve yarı zamanlı işlerin yaygınlaşması istihdam yapısını değiştirmiştir. Bunun neticesinde sendikalı işçilerin sayısı azalmış, sendikaların etkinliği gerilemiş ve sol partilerin esas destekleyicisi olan seçmenlerin desteği azalmıştır 
(Garrett, 1995, s. 663). Merkez sol partilerin seçmen tabanını oluşturan işçi sınıfı, ihracatı önceleyen politikalar ve orta sınıf ile parti programının kontrolüne yönelik mücadele içine girmiştir (Bernhard \& Leblang, 2002, s. 805).

Hem partilerin iktidarda kalma süreleri hem de partilerin ideolojileri açısından dönüşümlerini meydana getiren dönemler, ekonomik krizlerin yaşandığı zamanlardır. Demokratik sistemlerde krizler yeni programlarla yeni hükümetlerin iktidara gelmesini sağlar. Ekonomik krizler aynı zamanda baskı grupları arasındaki güç dağılımını etkiler. Baskı gruplarının bir kısmı güçlenirken, yeni dönem öncesi güçlü olan grupları zayıflatır. Merkez sağ partileri destekleyen çıkar grupları güçlenirse, reformların uygulanması açısından güçlü destek verirler (Haggard \& Webb, 1993, s. 153). Bu şartlar altında merkez bankası bağımsızlığı yürürlüğe konduktan sonra para politikasında esneklik kaybedilir (Lohmann, 1992). Bu durumun telafi edilebilmesi için, merkez bankası yönetimi para politikalarında ortodoks yaklaşımı benimsemeli, hesap verilebilirliği garantileyen, şeffaf ve etkin bir iletişim politikasını takip etmelidir (Masciandaro \& Romelli, 2016, s. 3). Siyasal partiler ideolojik tercihlerine uygun para politikası uygulama imkânını kaybederken, adeta reklam faaliyetlerine dönen ve piyasaların isteklerine uygun olan para politikası, teknokratlar tarafından bilimsellik ve uzmanlığa uygun şekilde yürütülmeye çalışılır.

\section{Çalışmanın Yöntemi}

Çalışmada Türkiye'de neoliberal dönüşüm sürecine uyum sağlama çabası içine giren siyasal partilerin, teknokratik yönetimin yerleştirilmesi açısından çok önemli bir yere sahip olan merkez bankası bağımsızlığı konusunda seçim beyannamelerindeki ifadeleri incelenmiştir. Bu amaçla Türkiye'de uygulamaya konan ve en temel neoliberal kurumsal dönüşümü ifade eden GEGP öncesi ve sonrasındaki 1999 ve 2002 yıllarında yapılan seçimlerden itibaren parlamentoda temsil edilmiş, iktidarda tek başına ya da koalisyon ortağı olarak bulunmuş ve ana muhalefet rolüne sahip siyasal partilerin seçim beyannameleri analiz materyali olarak seçilmiştir. Bu partiler ve tanımlayıcı bilgiler Tablo 1'de verilmiştir.

Tablo 1

Siyasal Partiler ve Tanımlayıcı Bilgiler

\begin{tabular}{c|c|c|c|c}
\hline Partiler & Kuruluş Tarihi & $\begin{array}{c}\text { Yasama/Yürütme } \\
\text { Görevi }\end{array}$ & İdeolojileri & $\begin{array}{c}\text { Yer Aldıkları } \\
\text { Kanat }\end{array}$ \\
\hline AK Parti & 2001 & $\begin{array}{c}\text { Tek Başına İktidar } \\
(2002)\end{array}$ & $\begin{array}{c}\text { Muhafazakâr- } \\
\text { Demokrat }\end{array}$ & Merkez Sağ \\
\hline CHP & 1923 & $\begin{array}{c}\text { Ana Muhalefet } \\
(2002)\end{array}$ & Sosyal Demokrat & Merkez Sol \\
\hline MHP & 1969 & $\begin{array}{c}\text { Koalisyon Ortağı } \\
(1999-2002)\end{array}$ & Milliyetçi & Sağ \\
\hline DSP & 1985 & $\begin{array}{c}\text { Koalisyon Ortağı } \\
(1999-2002)\end{array}$ & Sosyal Demokrat & Merkez Sol \\
\hline ANAP & 1983 & $\begin{array}{c}\text { Koalisyon Ortağı } \\
(1999-2002)\end{array}$ & Liberal & Merkez Sağ \\
\hline FP & 1997 & $\begin{array}{c}\text { Ana Muhalefet } \\
(1999-2002)\end{array}$ & Millî Görüş & Sağ \\
\hline
\end{tabular}


Belirlenen kısıtlar altında Adalet ve Kalkınma Partisi (AK Parti), Cumhuriyet Halk Partisi (CHP), Milliyetçi Hareket Partisi (MHP), Demokratik Sol Parti (DSP), Anavatan Partisi (ANAP) ve Fazilet Partisi (FP)'nin seçim beyannameleri incelenmiştir. Seçim beyannamelerinin seçiminde amaçlı örnekleme yöntemi kullanılmış ve eleştirel söylem analizi (ESA) yöntemiyle çözümlenmiştir. Söylem analizinin bir türü ESA (Fairclough, 2001), söylem ve sosyal uygulamaların diğer parçaları arasındaki diyalektik ilişkiyi analiz eder (Fairclough, 2001, s. 123; Chiapello \& Fairclough, 2002). Eleştirel realizme yatkın olan ESA, sadece söylem yerine toplumsal hayatın söylemsel ve materyal yönleri arasındaki ilişkiye odaklanır, kapsamlı metin analizleri yapılmasına firsat verir (Fairclough, 2013).

Fairclough (2003; 2010)'un ESA yöntemi, söylemlerden yararlanarak ideoloji, güç ve egemenlik ilişkilerini irdeleyen bir araçtır. Fairclough (2003, s. 4) günümüzdeki toplumsal ve ekonomik düzeni tanımlarken yeni kapitalizm kavramından yararlanır. Bu kavram ekonominin yanında siyaset, eğitim, sanatsal üretim ve sosyal yaşamın diğer alanlarını içerir. Neoliberalizm kavramı ise yeni kapitalizmin yayılması bakımından sosyal ilişkileri yeniden yapılandırmayı kolaylaştıran politik bir unsur olarak değerlendirilebilir.

\section{Analiz Yöntemi}

ESA modelinde metinlerin dilbilimsel boyutun yanında söylemin düzeni olarak adlandırılan dilin sosyal yapısı çerçevesinde de analiz edilmesi söz konusudur (Fairclough, 2003, s. 3). Bu bağlamda bir söylemin ya da bir ifadenin bir kavram ile eşleştirilmesi ve belirli bir bakış açısının böylece ifade edilmesi mümkün olmaktadır (Fairclough, 2013, s. 289-290). ESA modeli üç aşamadan oluşmaktadır (Fairclough, 2001, s. 125-126; 2003; 2010, s. 237; Chiapello \& Fairclough, 2002, s. 193). Modelin birinci aşamasında metnin tanımlanması yapılır. $\mathrm{Bu}$ aşamada analiz için ele alınan söylem metni; kelimeler, ilişkiler, dilbilgisi ve metnin yapısı açısından incelenirken, aynı zamanda geri planda bulunan ve doğrudan dile getirilmemiş düşünceler ortaya çıkarılmaya çalışlır.

Metinler arası/söylem düzeni olarak ifade edilen ikinci aşamada, incelemeye alınan metinler yorumlanır. Söylem metni, barındırdığı ilişkiler açısından incelemeye tabi tutulur ve başka hangi aktörlerin söylemleriyle benzerlik taşımakta olduğu, bu aktörlerden hangileri ortak olarak kabul edildiği ve dışlandığı ya da hangisinin dışlanmakta olduğu belirlenmeye çalışılır. Üçüncü aşama metnin sosyal yapılar etrafında açıklanmasını içerir. Metinlerin üretilmesi ve anlaşılması sosyal yapılara bağlı olduğundan, sosyal, kültürel, tarihsel, ekonomik ve siyasal bağlam açısından incelenir ve açıklanmaya çalışılır.

\section{Analiz Materyali: Partilerin Seçim Beyannameleri}

Seçim beyannameleri analiz edilirken, 1999 ve 2002 seçimlerine katılan partilerin beyannameleri seçimlerin tarihlerine göre metinler şeklinde sıralanmıştır.

Beyanname 1 (B1). “...DSP iktidarında para politikaları şu temel unsurlara dayandırılacaktır:

Para hacmindeki artış, ekonomik büyüme ile ve reel ekonominin gerekleri ile sınırl olacaktır. Merkez Bankasının kamuyu ve kamu destekleme alımlarını, dolayl da olsa, finanse etmesinin önüne geçilecektir. Hazine ve Merkez Bankası arasında, etkili ve sürekli çalışan bir eşgüdüm mekanizması oluşturulacaktır" (DSP 1999 Seçim Beyannamesi, s. 36-37).

Beyanname 2 (B2). "Uygulayacağımız orta vadeli program çerçevesinde, vergi gelirlerinin arttırılması ve kamu açıklarının azaltılmasıyla, para politikası üzerindeki Hazine baskısı azaltılacak ve bağımsız bir para politikası uygulanabilecektir. Merkez Bankası Kanunu'nda gerekli düzenleme yapılarak Hükümetin belirleyeceği iktisadi amaçlar çerçevesinde Merkez Bankasının kullanacă̆ı araçları özgürce seçebilmesi sağlanacaktır. Merkez 
Bankası şeffaflık ilkesine paralel olarak, uyguladığ politikaların sonuçlarını kamuoyuna ilan edecektir. Bu kurallara uyulması sonucunda piyasalara güven verilecek ve istikrar sağlanacaktır" (MHP 1999 Seçim Beyannamesi, s. 64-65).

Beyanname 3 (B3). "Türkiye ekonomisini AB üyeliğine ve Euro'ya hazırlayacak uyum yasalarının çıkartılması. İki yıl içinde enflasyonu \%5'e indirmek amacıyla para arzını düzenlemek ve bütçeyi dengelemek için gerekli bütün yasa ve kararnameleri 1999'da yürürlüğe koyacağız" (ANAP 1999 Seçim Beyannamesi, s. 14, 30).

Beyanname 4 (B4). "Orta vadeli program çerçevesinde kamu açıklarında sağlanacak daralma, verimlilik artışı ile uyumlu gelirler politikası, kamunun Merkez Bankası ve mali piyasalar üzerindeki baskısının hafiflemesi sonucunda para politikasının etkinliğinin artması ve sosyal güvenlik sistemindeki gibi yapısal reformlarda sağlanacak gelişmelere bağlı olarak enflasyonun tedricen düşmesi mümkün olacaktır” (FP 1999 Seçim Beyannamesi, s. 58).

Beyanname 5 (B5). "Ekonomide keyfi ve çıkarcı yönetime son vereceğiz. T.C. Merkez Bankası'nı özerkleștireceğiz” (CHP 1999 Seçim Beyannamesi).

Beyanname 6 (B6). "Merkez Bankası bağımsızlaştı. 4651 sayılı Türkiye Cumhuriyeti Merkez Bankası Kanunu'nda Değisşiklik Yapılmasına Dair Kanun, 5 Mayıs 2001 günü Resmî Gazete'de yayınlanmıştır. Kanunla; Merkez Bankası'nın temel amacının fiyat istikrarın sağlamak olduğu ve bankanın ülke para politikasının belirlenmesinde ve uygulanmasında tek yetkili ve sorumlu olduğu hükme bağlanmıştır. Böylece siyasal iktidarların Merkez Bankası üzerindeki baskısına son verilmiştir. Bu kanun sayesinde artık siyasal iktidarlar, karşılıksız para bastıramayacaktır” (DSP 2002 Seçim Beyannamesi, s. 28).

Beyanname 7 (B7). "Bağımsız para politikası uygulamak amacıyla Merkez Bankası daha özerk hale getirilmiştir” (MHP 2002 Seçim Beyannamesi, s. 10).

Beyanname 8 (B8). "Enflasyonla mücadelemizin temelini, devleti ekonomik faaliyetlerden çekerek rekabet alt yapısını güçlendirmek ve toplumsal verimliliği artırmak oluşturacaktır. Bunun için piyasaların düzenlenmesi, oyunun kurallarının belirlenmesi ve devletin sadece oyunun kuralların koyan ve denetleyen bir faktör olması sağlanacaktır. Bu çerçevede bütçe denetiminin etkinliği artırılacak ve bağımsız para politikası kararlılıkla uygulanacaktır" (ANAP 2002 Seçim Beyannamesi, s. 14).

Beyanname 9 (B9). "Para politikasında kısa dönemde enflasyonu düşüren, orta vadede ise fiyat istikrarına öncelik veren strateji sürdürülecektir. Merkez Bankası'nın bağımsızlı̆̆ korunacaktır. Uygulayacağımız ekonomik programda, para politikasının fiyat istikrarın esas alan stratejisi korunacaktır. Mali disiplinin sağlanmasına öncelik veren maliye politikalarıla, Merkez Bankasının enflasyonla mücadele etkinliği sağlanacaktır” (AK Parti 2002 Seçim Beyannamesi, s. 68, 83).

Beyanname 10 (B10). "Yasa ile öngörülen "Merkez Bankasinın bağımsızlı̆̆ı" ilkesi özenle korunurken, yönetimin işlemlerinde siyasi iradeye karşı saydam olmasını sağlayacağız. Yaratacağımız siyasi kararlılık ortamında, Merkez Bankasi'nın siyasi irade ile uyum çerçevesinde, enflasyon hedeflemesine geçmesini öngöreceğiz" (CHP 2002 Seçim Beyannamesi, s. 31).

\section{Bulgular ve Tartışma}

\section{Seçim Beyannamelerinin Metin Analizi}

Türkiye ekonomisinde neoliberal kurumsal ve yapısal temeli oluşturan ve 2001 yllında uygulamaya konulan GEGP'den önce, 1999 yılında yapılan seçimlerde siyasal partilerin seçim beyannamelerinde (B1, B2, B3, B4 ve B5) hem doğrudan hem de dolaylı şekilde para politikasının yönetiminde ve enflasyonun kontrol altına alınmasında, teknokrasinin ve bağımsız merkez bankasının etkin olduğuna dair cümleler bulunmaktadır. Merkez bankası bağımsızlı̆̆ına yönelik doğrudan ifadeler B2 ve B5’teki metinlerde göze çarpmaktadır. B2'de 
merkez bankası bağımsızlığını tesis edebilmenin yolu olarak "kamu açıklarının azaltılması", "para politikası üzerindeki Hazine baskısının azaltılması” gösterilmektedir. Ayrıca B2'de yasal düzenlemelerle MB'nin "kullanacağı araçları özgürce seçeceğì" belirtilmiştir. Bunun yanı sıra piyasalara güven verebilmek amacıyla ve istikrar sağlaması açısından MB'nin şeffaf bir politika uygulayacağı vurgulanmaktadır. B2'de MB'nin bağımsız olması konusunda "kamu açıklarının azaltılması" ve "piyasalara güven verilmesi ve istikrar sağlanması" gerekçeleri öne çıkarılmıştır. B5'te ise doğrudan MB'nin özerkleştirileceği ifade edilmiş ve MB'nin bağımsız olması gerekçesi olarak "ekonomide keyfi ve çıkarcı yönetime son verilmesi” iddiası öne sürülmüştür.

B1, B3 ve B4’te doğrudan merkez bankası bağımsızlığına yönelik ifadeler bulunmamasına karşlık, para politikalarının kural temelli yönetilmesine ve neoliberalizmin desteklediği şekilde sınırlandırılmasına vurgu yapılmaktadır. Bl'de "para hacmindeki artışın sınırlandırılması" ve "MB'nin kamu ve kamu destekleme alımlarını, dolaylı olsa da, finanse etmesinin önüne geçilecektir” ifadesi kullanılarak MB'nin mali disiplini sağlama fonksiyonuna da vurgu yapılmıştır. B3’te "Euro'ya hazırlayacak uyum yasalarının çıkartılması" ve "para arzını düzenlemeye yönelik" yasal düzenlemelerin yapılması öne çıarılmıştır. Burada hem Euro gibi uluslararası norm hedef olarak gösterilmiş hem de iç piyasada para arzını düzenlemede politikaların yasalar çerçevesinde belirlenmesine vurgu yapılarak bağımsız merkez bankası düzenlemelerinin önü açılmıştır. B4’te ise "kamu açıklarında sağlanacak daralma", "kamunun merkez bankası üzerindeki baskısının hafiflemesi" yoluyla para politikasının etkinliğinin artmasına vurgu yapılmıştır. Böylece merkez bankasının sadece para politikasına ve fiyat istikrarına odaklanmasına yönelik politikaların desteklenmesi söz konusudur.

2002 yılında yapılan seçimlere yönelik hazırlanan seçim beyannamelerinde ise doğrudan merkez bankası bağımsızlığına yapılan vurgular göze çarpmaktadır. B6, B7, B8, B9 ve B10 metinlerinde bu vurgunun doğrudan yapıldığı görülür. B6'da iktidarda bulundukları dönemde çıkan MB Kanunu ile merkez bankasının temel amacı "fiyat istikrarın sağlamak" ve "para politikasının belirlenmesinde ve uygulanmasında tek yetkili ve sorumlu olması" öne çıkarılmıştır. Bunun temel gerekçesi olarak da "siyasal iktidarların karşılıksız para bastıramamaları" gösterilmiştir. B7 ve B8'de MB bağımsızlığı vurgulanırken, burada bağımsız para politikası uygulanmasına devam edileceği seçmenlere ilan edilmiştir. B8'de aynı zamanda "piyasaların düzenlenmesi", "oyununun kurallarinin belirlenmesi" ve "devletin sadece oyununun kurallarinı koyan ve denetleyen" bir konumda olması öne çıkarılmış, piyasaya müdahale edilmeyeceği ilan edilmiş ve MB bağımsızlığını destekleyecek yapısal düzenlemelerin gerekliliği ifade edilmiştir. B9'da bir önceki hükümet döneminde yasalaştırılan MB bağımsızlığının korunacağı beyan edilmiş, "enflasyonu düşürmede" ve "orta vadede fiyat istikrarına öncelik veren" politikaların sürdürüleceği ve bu hedeflere ulaşmada merkez bankası bağımsızlığının önemi belirtilmiştir. Ayrıca mali disiplinin sağlanmasına yönelik politikalarla "Merkez Bankasının enflasyonla mücadele etkinliğini sağlama" amacının önemi dile getirilmiştir. B10'da "Merkez Bankası'nın bağımsızlı̆̆g” ilkesinin korunacağı ve "enflasyon hedeflemesine" geçileceği vaat edilmiştir.

1999 ve 2002 yıllarında seçimlere katılan, iktidar ya da ana muhalefet konumuna yerleşen partiler, hangi ideolojik konumda yer alırsa alsın, para politikasındaki esnekliklerden MB bağımsızlığı yoluyla vazgeçmişlerdir. Böylece her biri farklı ideolojiye sahip olan partiler, neoliberal yaklaşımı benimsediğini açıllayarak dünya sistemine uyumu esas aldıklarını hem iç hem de dış kamuoyuna ilan etmişlerdir. Aynı zamanda tam anlamıyla Keynesyen Refah Devleti'ne özgü politikalar rafa kaldırılmıştır. Burada özellikle solda yer alan ve işçi sınıfının haklarını göz önünde tutması beklenen CHP ve DSP’nin sosyal politikaları ve işsizliğe yönelik toplumsal sorunları neoliberal söylem içine yerleştirdikleri dikkat çekmektedir. Bu siyasal partilerin ideolojik farklılıkları, paranın nötr olmasını kabul etme ve para politikasından siyasetin dışlanması bağlamında ortadan kalkmıştır. $\mathrm{Bu}$ durum partilerin hepsinin para politikalarında teknokratların ve uzmanların yönetiminde dünyada hâkim paradigma olan neoliberalizmi kabul ettiğini göstermektedir. Dolayısıyla partiler iktidara geldiğinde hem kredibilite tesis etmek hem de geleceği belirli hale getirerek iktidarlarının sürekliliğini 
sağlamayı amaçlamaktadırlar. Bu tercihlerden ötürü, ele alınan dönem itibariyle Türkiye ekonomisinde, uluslararası normlar ve egemen ideolojinin toplumsal talep ve sorunların önüne geçirilmiş olduğu söylenebilir.

\section{Seçim Beyannamelerinin Metinler Arası Analizi}

Seçim beyannamelerinde (B1, B2, B3, B4, B5, B6, B7, B8, B9 ve B10) merkez bankası bağımsızlı̆̆ına yönelik seçmenlere ilan edilen söylemler, sadece para politikasına dair iyileştirilmeyi değil, bunun yanı sıra farklı unsurları içinde barındırmaktadır. Siyasal partiler seçim beyannameleri yoluyla vaatlerin ötesinde ekonomik, siyasal, ideolojik ve sosyal alana dair geri planda kalan gerekçeleri de anlatmaktadır. Dünya ekonomisinde yeni bir evrensel bilinç öngören neoliberal düşünce, küreselleşmeyi adeta kendi dili etrafında şekillendirirken, teknokrasiyi ekonomi yönetiminde yerleştirmede demokrasi, birey, yönetişim, esneklik kavramlarını bir propaganda aracı olarak kullanmaktadır. Bu dilin ve söylemlerin etkisini ortaya koymakta metinler ve metinler arası etkileşim, ilişkiler ve bunlar üzerinde etkili olan örtük yapılar belirginleştirilmelidir (Fairclough, 2013, s. 282). 1999 yılındaki seçimlere yönelik hazırlanan seçim beyannamelerinde Bl'de para politikasının "ekonomik büyüme ve reel ekonominin gerekleri” ile sınırlı olması gerektiği ifade edilmektedir. Dolayısıyla para arzındaki genişlemenin ekonomik büyüme oranına bağlanmasını isteyerek, Friedman (1963) tarafından öne sürülen ve neoliberalizmin dayandığı temel düşünceler desteklenmektedir. $\mathrm{Bu}$ tercih ise dolaylı olarak işsizlik politikalarının para politikasından dışlanmasının benimsendiğini göstermektedir. B2 ve B4'te ise orta vadeli program ile mali disiplin yoluyla kamu açıklarının azaltılması öne çıkarılmıştır. Her iki beyannamede kamu açıklarının enflasyona neden olduğunu kabul edilmekte ve Keynesyen refah devleti uygulamaları göz ardı edilmektedir. Diğer bir ifadeyle enflasyonun nedeni olarak görülen kamu harcamalarını azaltıp, sosyal politikaları devlet elinden almak hedeflenmektedir. B3 ise "AB üyeliği ve Euro'ya hazırlanma" ifadesini kullanarak uluslararası bir çapayı gündeme getirmiştir. “...para arzını düzenlemek ve bütçeyi dengelemek” amaçları için de bir yol gösterici kabul edilmiştir. Bu tercihlerle birlikte Euro bölgesinde olduğu gibi bağımsız merkez bankasının sadece fiyat istikrarına odaklanması tasarlanmaktadır. Böylece bu beyannamede de uluslararası bir çapa yoluyla uluslararası normlara uyum öne çıkartılmıştır. Egemen neoliberal ideoloji kabul edilirken, başka bir uygulama örnek olarak gösterilmiştir. B5’te ise doğrudan “T.C. Merkez Bankası'nı özerkleştireceğiz" ifadesi kullanılmıştır. Böylece para politikası ve ekonomi yönetiminde teknokratlaşma ve siyasetten arındırılma tam anlamıyla kabul edilmiş, "ekonomide keyfi ve çıkarcı yönetime son vereceğiz" ifadesiyle bu yaklaşım ilan edilmiştir.

Türkiye'de yapısal dönüşümün neoliberal ideoloji etrafında kurumsal düzeyde tamamlandığı 2001 yılındaki GEGP'den sonra 2002 yılında yapılan seçimlere yönelik partilerin ilan ettikleri seçim beyannamelerinde hem iktidar ortağı olan partiler hem de muhalefet partileri, yasal bakımdan bağımsız merkez bankasının varlı̆̆ını kabul etmişler ve bunu devam ettireceklerini ilan etmişlerdir. B6, B7, B8, B9 ve B10'da merkez bankasının yasal bağımsızlığı vurgulanmış ve devam ettirileceği deklare edilmiştir. Bağımsız merkez bankasının “temel amacı fiyat istikrarını sağlamak ve para politikasında ... tek yetkili ve sorumludur" (B6), "bağımsız para politikasını uygulamak amacı" (B7), "Merkez Bankası'nın bağımsızlığı korunacaktır” (B9) ve “Merkez Bankası'nın bağımsızlı̆̆ ilkesi özenle korunurken” (B10) ifadeleriyle, uzman ve teknokrat yönetim hemen hemen birbirinden farklı ideolojilere sahip partiler tarafından kabul edilmiştir. B8'de ise enflasyonla mücadelede devletin fonksiyonları tanımlanırken, devletin belirtilen işlevleri çerçevesinde "bağımsız para politikası kararllıkla uygulanacaktır" denilerek merkez bankasının bağımsızlığı öne çıkarılmıştır. Böylece küresel bir söylem, taklit ya da zihinsel kabul ediş yoluyla (McNamara, 2002; 2008) ulusal bir düzene dönüştürülmüştür. Diğer taraftan neoliberal söylem, düşüncelerini siyasal partiler yoluyla topluma duyurmuş ve bundan önceki diğer söylemler üzerinde yıkıcı etkilere yol açmıştır (Fairclough, 2013, s. 290-291). Para politikaları, neoliberal söyleme uygun olarak toplumsal taleplerden soyutlanmış, siyaset de böylece para politikasının belirlenmesi yoluyla teknokratların eline terk edilmiştir. 2002 yılındaki seçim beyannamelerinde bütün sağ partiler Nordhaus (1975) ve Hibbs (1977)'in görüşünü destekler biçimde destek vermiştir. Burada ilginç olan, sol 
partilerin de bu görüşleri benimsemesi ve Garrett $(1995 ; 1998)$ tarafından tanımlanan dönüşüm içine girmiş olmasıdır. Çünkü para politikasında esneklik kaybını kabul etme, enflasyonla mücadelenin emek üzerine kalması anlamına gelir. Kendilerini sol olarak tanımlayan partilerin bu dönüşümü kabul etmesi, sınıf temelli siyasetin ortadan kalkması çıkar temelli siyaseti güçlendirmiş (Hall, 2010) ve kimliklere dayalı "total siyasetin" (Karakoç, 2020) de öne çıkmasına aracı olmuştur. Türkiye'de bütün siyasi partiler seçmenlerine karşı farklı ideolojilere sahip olduklarını vurgulasalar da neoliberalizmin dönüştürücülüğünde her biri neoliberalleşme sürecini ideolojik olarak tamamladıklarını göstermektedir.

\section{Seçim Beyannameleri Metinlerinin Bağlamsal Analizi}

"Merkez bankasının kamuyu" (B1), "kamu destekleme alımlarını, dolaylı olsa da, finanse etmenin önüne geçilecektir" (B1), "vergi gelirlerinin arttırılması" (B2), "kamu açıklarının azaltılması" (B2), "para politikası üzerinde Hazine baskısı azaltılacak” (B2), "piyasalara güven verilecek” (B2), “istikrar sağlanacak” (B2) "enflasyonu \%5'e indirmek" (B3), "para arzını düzenlemek" (B3), "bütçeyi dengelemek" (B3), "kamu açılarında sağlanacak daralma” (B4), "verimlilik artışı ile uyumlu gelirler politikası" (B4), "kamunun merkez bankası üzerindeki baskısının hafiflemesi” (B4), "para politikasının etkinliğinin artması” (B4), "yapısal reformlarda sağlanacak gelişmeler" (B4), "enflasyonun tedricen düşmesi” (B4) 1999 yılındaki seçim beyannameleri dikkate alındığında, bu metinlerin hangi bağlamda üretildiği değerlendirilebilir. Bu dönem 24 Ocak 1980 kararları ile ekonomideki yapısal dönüşümün gerçekleştirildiği ve "yeni bir insan tipi” yaratarak dünya ekonomisine uyumu hedefleyen sürecin devamıdır. Bununla birlikte 32 sayılı karar ile 1989 yılında Türk lirasının konvertibl olması sermaye hareketleri önündeki engellerin kaldırıldığı ve küreselleşmenin kapsama alanına girdiği diğer bir dönüşüm devresinin etkilerinin görüldüğü dönemdir. Kamu açıklarının artması ve iç tasarrufun yetersizliği ekonomik büyüme üzerinde negatif etkiler oluşturduğundan, sermaye hareketlerinin serbestleştirilmesi, dış finansmana dayalı büyümenin önünü açmıştır (Sönmez, 2009, s. 42). Sermaye hareketlerinin serbestleşmesinden sonraki 1990'lı yllarda enflasyon oranı \%50'nin üzerinde istikrarlı bir seyir izlerken, siyasetin içine düştügü istikrarsızlık, kamu gelirlerinin üzerinde kamu harcamasının sermaye girişlerine dayalı olarak yapılmasını teşvik etmiştir. Yeterli vergi gelirlerinin elde edilememesi, borçlanmayı daha da fazla artırmıştır. Yüksek borçlanma neticesinde borç yükü, neredeyse vergi gelirlerinin toplamına eşit hale gelmiştir. Böylece Türkiye, yüksek borç ve yüksek enflasyon sarmalına tutulmuştur. Öte yandan sermaye hareketlerinin serbestliği altında, makroekonomik politikalar ve büyüme süreci, sermaye süreci ile desteklenen büyümeye bağlı kılınmıştır. Bu yolla büyümenin sağlanmaya çalışılması, cari açığın dönem içinde artmasına yol açmıştır. Dolayısıyla Türkiye ekonomisinin büyümesi ve ekonomide elde edilmesi gereken tasarruflar, finansal hareketlere ve küresel finans piyasasındaki gelişmelere duyarlı hale gelmiştir. Bu yapısal sorunlar, Türkiye'nin 1994, 1999, 2000 ve 2001 yılında olmak üzere toplam dört tane ekonomik kriz yaşamasına neden olmuştur (Pamuk, 2004, s. 395; Yenal, 2003, s. 106; Yeldan, 2013, s. 37). Bütün bu süreçlerin etkileri kendisini seçim beyannamelerinde de göstermiş, kamu açıklarını azaltmak, bütçe dengesini sağlamak, kamu açılarının merkez bankası tarafından yapılmasını engellemek temel amaç şeklinde ifade edilmiştir. Bu yolla enflasyonu düşürmek partiler açısından mümkün görünürken, bunun yanı sıra B1, B2, B3 ve B5’te görüleceği üzere, merkez bankasının yasal ve fiili bağımsızlı̆̆ı öne çıkarılmıştır.

1999 yılında yapılan seçimlerden sonra kurulan koalisyon hükümetini kuran partilerin seçim beyannamelerindeki (B1, B2 ve B3) ifadelere uygun olarak, 1999 yllında yürürlüğe giren 17. destekleme düzenlemesiyle enflasyonu düşürmek için para tabanındaki genişleme, para kurulunu andırır biçimde Merkez Bankasının net dış varlıklarında elde edeceği artışa bağlanmıştı. Böylece merkez bankası, döviz girişi karşılığında piyasaya para sürecekti. Para talebinde oluşacak artı̧̧ faiz oranlarını yükseltirken, Türkiye'ye girecek sermaye ile likidite ihtiyacı karşılanmış olacaktı. Merkez bankası para kurulu işlevini üstlenirken, bu yapıyı destekler şekilde sabit döviz kuru sistemine dayalı döviz kuru çapası sistemi uygulanmaya başlandı. Bu sistem altında dövizin değerindeki artış enflasyon oranının altında kalacak ve döviz kurunda sağlanan istikrara 
bağlı olarak, Türkiye’ye sermaye girişi sağlanacak, enflasyon oranı da düşürülmüş olacaktı (Kazgan, 2012, s. 227-228). Türkiye'de para politikasının bu şekilde kurala bağlanması ve döviz kuru çapası uygulamaya geçilerek sabit döviz kuru sisteminin yürürlüğe girmesi, Bernhard, Broz ve Clark (2002, s. 706) tarafından belirtildiği gibi kredibilite ile esneklik arasındaki ters yönlü ilişkiyi gündeme getirdi. Fiyat istikrarını tesis etme görevini merkez bankasına devredildiğinde kredibilite kazanan hükümetler, ülkede oluşacak beklenmedik dalgalanmalarda politik bağımsızlığını kaybettiğinden esneklik sorunu ortaya çıktı.

“Merkez Bankasının temel amacının fiyat istikrarını sağlamak olduğu” (B6), "para politikasının belirlenmesinde ve uygulanmasında tek yetkili ve sorumlu olduğu" (B6), "siyasal iktidarların Merkez Bankası üzerindeki baskısına son verilmiştir" (B6), "siyasal iktidarlar karşıllksız para bastıramayacaktır" (B6), "bağımsız para politikası" (B7), "Merkez Bankası daha özerk hale getirilmiştir" (B7), "devleti ekonomik faaliyetlerden çekerek” (B8), "piyasaların düzenlenmesi" (B8), "devletin sadece oyununun kuralların koyan ve denetleyen bir faktör olması" (B8), "bütçe denetiminin etkinliği" (B8), "bağımsız para politikası" (B8), "kısa dönemde enflasyonu düşüren" (B9), "orta vadede ise fiyat istikrarına öncelik veren” (B9), "Merkez Bankası'nın bağımsızlğ̆ korunacaktır" (B9), "para politikasının fiyat istikrarını esas alan stratejisi” (B9), "mali disiplinin sağlanması" (B9), "yasa ile öngörülen" (B10), "Merkez Bankasının bă̆ımsızlı̆ı" (B10) ve "enflasyon hedeflemesi” (B10) ifadeleri partilerin 2002 seçimlerinden önce beyanname metinlerini hangi bağlamda ürettiğini değerlendirebilme imkânı vermektedir. 2002 seçimlerinden sonra tek başına iktidara gelen AK Parti de seçim beyannamesinde (B9), içinde yer aldığ 1 ve 2001 yılında ayrıldığı Fazilet Partisinin seçim beyannamesinde ifade ettiği (B4) kurumsal dönüşümü daha açık bir şekilde para politikası ve merkez bankası bağımsızlığı hususunda devam ettirmiştir. Bu durum, partilerin seçim beyannameleri ile Türkiye'de dünya ekonomisine eklemlenmeyi içeren üçüncü dönüşüm sürecini desteklediklerini göstermektedir.

2001 yılında yaşanılan krizden sonra uygulamaya konulan GEGP ile Türkiye ekonomisinde yapısal dönüşümler hedeflenirken, en önemli yanı kurumsal düzenlemeler vasıtasıyla siyasetin ekonomi yönetimi üzerindeki etkisinin azaltılmasıydı. Hem normatif hem de zorlayıcı eş yapılanma modelleri etrafında uygulamaya konulan program, dağılım ilişkilerini, sosyal güvenlik sistemini, finansal sistemi, ekonomik alt yapı ile kamu yönetiminde yeni baştan dönüşümü (Boratav, 2007, s. 184) içine alan çok kapsamlı bir paradigma değişimini beraberinde getirmişti. Bu amaca uygun olarak Türkiye Cumhuriyet Merkez Bankasının siyasetten bağımsız hale getirilmesi amacıyla bağımsızlığı güçlendirildi ${ }^{7}$. Paranın bir nesne olmanın ötesinde işlevini öne çıkaran bu bakış açısı, aynı zamanda sosyal haklar yanında ulus devletin en önemli temsilcisi olan paranın siyasal işlevini kaybetmesiyle sonuçlandı. Politika aracı olarak paranın ulus devletin sübjektif değer yargısı yerine teorinin objektif yargısı içine alınması, siyasetin ekonomiden uzaklaşmasını hızlandırdığı gibi teknokratik yapı etrafında bireylerin, para aracılığıyla nesnelleşmesini hızlandırdı. Para üzerinde bu şekilde teknokratik yönetim sağlanırken, oyun alanını netleştirmeye yönelik ve rekabeti engelleyerek işlem maliyetlerini artıran kurumsal düzenlemeler uygulamaya konuldu. Üçü tarımsal destekleme politikalarını ortadan kaldıran, diğerleri ise enerji, telekomünikasyon, ihaleler ve bankacılık alanlarının düzenlemesinden oluşan, siyasetten bağımsız özerk kuruluşlar oluşturuldu (Bayramoğlu, 2010; Sönmez, 2011).

\section{Sonuç}

Neoliberal düşüncenin öne çıkarttığı merkez bankası bağımsızlı̆̆ı, para politikasının teknokrasinin ilkeleri etrafında bilimsellik ve uzmanlık yaklaşımını benimseyen kişilerin yönetiminde piyasa önceliklerine uygun yönetilmesi düşüncesidir. Hükümetler ve siyasal partiler hem kredibilite kazanmak hem de gelecekteki belirsizliği azaltmak için bu yapıya uyum sağlama çabası içine girerler. Uluslararası piyasalarda güven tesis etmek amacıyla girilen bu yapısal dönüşüm sürecinde, fiyat istikrarını tesis ederken, ellerindeki en önemli

\footnotetext{
${ }^{7}$ Konu ile ilgili detaylı bilgi için bakınız; TCMB (2021).
} 
politika aracından vazgeçmek zorunda kalmışlardır. Böylece küresel yapılanmaya uyum sağlanırken, bu yapı taklit ya da zihinsel kabul ediş yoluyla (McNamara, 2002; 2008) ulusal bir düzene dönüştürülmüştür. Neoliberal düşünce siyasal partiler yoluyla topluma kabul ettirilmiştir (Fairclough, 2013). Teknokrasinin yönetiminde para politikaları öne çıarılmış ve 2002 yılındaki seçim beyannamelerinde bütün sağ partiler (Nordhaus, 1975; Hibbs, 1977) destek vermiştir. Burada ilginç olan sol partilerin de bu görüşleri benimsemesi ve Garrett $(1995 ; 1998)$ tarafından tanımlanan dönüşüm içine girmiş olmasıdır. Çünkü para politikasında esneklik kaybını kabul etme, enflasyonla mücadelenin emek üzerine kalmasını doğurmaktadır. Sol partiler olarak tanımlanan partilerin bu dönüşümü kabul etmesi, sınıf temelli siyasetin ortadan kalkmasıyla çıkar temelli siyaseti güçlendirmiş (Hall, 2010) ve kimliklere dayalı "total siyasetin" (Karakoç, 2020) de öne çıkmasına aracı olmuştur. Bu tercih ister istemez devletin ekonomiden el çekmesini, kendi vatandaşları arasındaki fırsat eşitliğini piyasalar yoluyla sağlamasını ve rasyonel davranışı temel alan teknokrasi çerçevesinde toplumsal aktörlerin isteklerini dikkate almaya siyaseti zorlar. Uyum sağlamaya çalışılan bu ilkeler, neoliberal düşüncenin desteklediği ve bilimsellik etrafında evrensellik ilkesi kazanan merkez bankası bağımsızlığı, ülkelerin kendi toplumsal şartlarının göz ardı edilmesine yol açar. Bunun yanı sıra para politikasında siyasal partilerin ideolojilerinin dışlanması, nötr para yaklaşımını hâkim kılarken, toplumsal sorunlarda paranın tarafsızlaşmasını beraberinde getirir. Böylece siyaset para politikasından dışlanmış, kendi seçmenleri ve ülkenin vatandaşları karşısında yansızlık ilkesini öne çıarmak zorunda kalmıştır. Toplumsal sorunlar karşısında yansızlaşan para ve para politikası, dünya ekonomisinde benzer politikaların uygulanmasını hızlandırmış ve ülkelerin kendi şartlarına göre politika uygulama imkânını ortadan kaldırmıştır. Dolayısıyla siyasal partiler, hâkim ideoloji olan neoliberalizme ekonomi politikalarında uyum sağlarken, kendi ideolojilerini yitirmek zorunda kalmışlardır. Diğer bir ifadeyle partiler, paranın depolitizasyonu neticesinde ideolojisizleşme ve neoliberal benzeşme süreci içine girmişlerdir.

Türkiye ve Türkiye'deki siyasal partilerde bu süreçten kendisini bağımsız kılamamıştır. 1990’lı yıllarda yaşanan siyasal ve ekonomik istikrarsızlıklar, dünya ekonomisine uyum sürecini hızlandırmıștır. Araştırmada ele alınan siyasal partiler merkez sağ, merkez sol, milliyetçi ve milli görüşçü ideolojilere sahip olsalar da yaşanan ekonomik sorunların çözümünü dünyada egemen olan neoliberal ideolojiye uyum sağlamakta bulmuştur. 90'lı yllların sonunda yapılan 1999 seçimlerinde ele alınan siyasal partilerin her biri (DSP, MHP, ANAP, FP ve CHP) bağımsız merkez bankasının önünü açacak ifadelere seçim beyannamelerinde yer vermişlerdir. Yaşanan ekonomik krizler ve siyasal istikrarsızlıklar partileri bu tercihe zorlarken, her biri ideolojilerinden uzaklaşmış ve kendi ellerini ekonomi yönetiminde bağlayan politikaları desteklemiştir. 2001 yılında uygulamaya konan ve neoliberal kurumsal dönüşümleri kapsayan GEGP öncesi, bütün partiler kendi seçmenlerini bu programın şartlarına hazırlamıştır. Nitekim iktidara geldiklerinde bu partilerin, para politikasında aynı kurumsal dönüşümün hazırlığını yaptıkları görülmektedir. 2002 yılında ve GEGP’nin yürürlükte olduğu dönemde yapılan seçimlerde, programı uygulayan iktidar ortağı olan partiler (DSP, MHP ve ANAP) ile birlikte o dönem ilk defa seçime girip tek başına iktidar olan (AK Parti) ve ana muhalefet görevini alan parti (CHP), yasalaşan MB bağımsızlığını devam ettirme taahhüdünde bulunmuştur.

2001 yllında yaşanan ekonomik krizden sonra uygulamaya konulan GEGP çerçevesinde bağımsız hale getirilen MB’nin bu yönetim yapısının devam ettirileceği, açık bir şekilde her bir siyasi partinin seçim beyannamesinde ifade edilmiştir. Böylece neoliberalizmin temel yaklaşımı nötr para anlayışı etrafında para politikasının yönetiminin teknokrasiye terk edilmesine tüm partiler destek vermiştir. Artık siyasal partiler ekonomi politikalarında meşruiyetlerini teknokrasiden sağlamaya yönelmiştir.

Sonuç olarak, Türkiye'de bütün siyasal partiler neoliberal ideolojiye uyum sağlarken, kendi ideolojilerini geri plana atmıştır. Toplumsal sorunlar para politikalarında geri plana itilirken, "çok parti tek ideoloji” Türk siyasal hayatında ekonomi politikalarında hâkim kılınmıştır. Böylece her bir siyasal parti, bir neoliberal siyasal organa dönüşmüştür. 


\section{Kaynakça}

Agoba, A. M., Abor, J., Osei, K. A. ve Sa-Aadu, J. (2017). Central bank independence and inflation in Africa: The role of financial systems and institutional quality. Central Bank Review, 17(4), 131-146. doi: 10.1016/j.cbrev.2017.11.001

Ak Parti (2021). Hakkında. Erişim adresi: https://www.akparti.org.tr

Alesina, A. (1988). Macroeconomics and politics. S. Fischer içinde, NBER macroeconomics annual vol. 3 (s. 13 62). MIT Press.

Alesina, A. F. ve Stella, A. (2010, April). The politics of monetary policy. NBER Working Paper Series (No: 15856).

Alesina, A. ve Gatti, R. (1995). Independent central banks: Low inflation at no cost? American Economic Review, 85(2), 196-200. Erişim adresi: https://www.jstor.org/stable/2117918.

Alesina, A. ve Tabellini, G. (2008). Bureaucrats and politicians? Part II: Multiple policy tasks. Journal of Public Economics, 92, 426-447. doi:10.1016/j.jpubeco.2007.06.004

Amable, B. (2011). Moral and politics in the ideology of neoliberalism. Socio-Economic Review, 9(1), 3-30. doi:10.1093/ser/mwq015

ANAP (2021). Hakkında. Erişim adresi: https://anavatan.org.tr

Arrighi, G. (1990). The three hegemonies of capitalism. Review (Fernand Braudel Center), 13(3), 365-408. Erişim adresi: https://www.jstor.org/stable/40241160.

Bagheri, F. M. ve Habibi, N. (1998). Political institutions and central bank independence: A cross-country analysis. Public Choice, 96(1/2), 187-204. Erişim adresi: https://www.jstor.org/stable/30024383.

Barro, R. J. ve Gordon, D. B. (1983a). Rules, discretion and reputation in a model of monetary policy. Journal of Monetary Economics, 12(1), 101-121. doi: 10.1016/0304-3932(83)90051-X

Barro, R. J. ve Gordon, D. B. (1983b). A positive theory of monetary policy in a natural rate model. The Journal of Political Economy, 91(4), 589-610. Erişim adresi: https://www.jstor.org/stable/1831069.

Bayramoğlu, S. (2010). Yönetişim zihniyeti Türkiye'de üst kurullar ve siyasal iktidarın dönüşümü. İstanbul, Türkiye: İletişim Yayınları.

Bernhard, W. ve Leblang, D. (2002). Political parties and monetary commitments. International Organization, 56(4), 803-830. doi: 10.1162/002081802760403784

Bernhard, W., Broz, J. L. ve Clark, W. R. (2002). The political economy of monetary institutions. International Organization, 56(4), 693-723. doi: 10.1162/002081802760403748

Bertsou, E. ve Caramani, D. (2020). People haven't had enough of experts: Technocratic attitudes among citizens in nine European democracies. American Journal of Political Science, 1-19. doi: 10.1111/ajps.12554

Berument, H. ve Neyaptı, B. (1999). Türkiye Cumhuriyet Merkez Bankası ne kadar bağımsız? İktisat, Isşletme ve Finans Dergisi, 14(165), 11-17. doi: 10.3848/iif.1999.165.5480

Bickerton, C. ve Accetti, C. I. (2017). Populism and technocracy: Opposites or complements? Critical Review of International Social and Political Philosophy, 20(2), 186-206. doi: 10.1080/13698230.2014.995504 
Bodea, C. ve Higashijima, M. (2017). Central bank independence and fiscal policy: Can the central bank restrain deficit sprending? British Journal of Political Science, 47(1), 47-70. doi: $10.1017 /$ S0007123415000058.

Boyer, R. (2013). The present crisis: A trump for a renewed political economy. Review of Political Eonomy, 25(1), 1-38. doi: 10.1080/09538259.2013.736262.

Brumm, H. J. (2011). Inflation and central bank independence: Two-way causality. Economic Letters, 111, 220222. doi: 10.1016/j.econlet.2011.02.005.

Caramani, D. (2017). The populist and technocratic forms of political representation and their critique to party government. Annual Political Science Review, 111(1), 54-67. doi: 10.1017/S0003055416000538.

Centeno, M. A. (1993). The new leviathan: The dynamics and limits of technocracy. Theory and Society, 22(3), 307-335. Erişim adresi: https://www.jstor.org/stable/657736.

Centeno, M. A. ve Cohen, J. N. (2010). Global capitalism: A sociological perspective. MA: Polity Press.

Centeno, M. A. ve Cohen, J. N. (2012). The arc of neoliberalism. Annual Review of Sociology, 38, 317-340. doi: 10.1146/annurev-soc-081309-150235.

Cerny, P. G. (1997). Paradoxes of the competition state: The dynamics of political globalization. Government and Opposition, 32(2), 251-274. doi: 10.1111/j.1477-7053.1997.tb00161.x.

Chiapello, E. ve Fairclough, N. (2002). Understanding the new management ideology: A transdisciplinary contribution from critical discourse analysis and new sociology of capitalism. Discourse and Society, 13(2), 185-208. doi: 10.1177/0957926502013002406.

CHP (2021). CHP Tarihi. Erişim adresi: https://www.chp.org.tr/haberler/chp-tarihi

Christensen, J. veMandelkern, R. (2021). The technocratic tendencies of economists in government bureaucracy. Governance, 1-25. doi: 10.1111/gove.12578.

Chwieroth, J. (2007). Neoliberal economists and capital account liberalization in emerging markets. International Organization, 61(2), 443-463. doi: 10.1017/S0020818307070154.

Cohen, B. J. (1977). Organizing the world's money the political economy of international monetary relations. London, UK: The MacMillan Press Ltd.

Crowe, C. (2008). Goal independent central banks: Why politicians decide to delegate. European Journal of Political Economy, 24(4), 748-762. doi: 10.1016/j.ejpoleco.2008.05.002.

Crowe, C. ve Meade, E. E. (2007). The evolution of central bank governance around the world. Journal of Economic Perspectives, 21(4), 69-90. doi: 10.1257/jep.21.4.69.

Crowe, C. ve Meade, E. E. (2008). Central bank independence and transparency: Evolution and effectiveness. European Journal of Political Economy, 24(4), 763-777. doi: 10.1016/j.ejpoleco.2008.06.004.

Cukierman, A. (1992). Central bank strategy, credibility and independence: Theory and evidence. Cambridge, UK: MIT Press.

Cukierman, A. (1994). Commitment through delegation, political influence and central bank independence. J. O. Wijnholds, S. Eijffinger veL. H. Hoogduin içinde, A framework for monetary stability (s. 55-74). Dordrecht, NE: Kluwer Academic Publishers. 
Cukierman, A. ve Lippi, F. (2001). Labor markets and monetary union: A strategic analysis. The Economic Journal, 111, 541-565. doi: 10.1111/1468-0297.00650.

Cukierman, A., Webb, S. B. ve Neyapti, B. (1992). Measuring the independence of central banks and its effects on policy outcomes. The World Bank Economic Review, 6(4), 353-398. Erişim adresi: https://www.jstor.org/stable/3989977.

de Haan, J., Bodea, C., Hicks, R. ve Eijffinger, S. C. (2018). Central bank independence before and after the crisis. Comparative Economic Studies, 60, 183-202. doi: 10.1057/s41294-017-0050-4.

Duménil, G. ve Lévy, D. (2005). The neoliberal (counter-) revolution. A. Saad-Filho veD. Johnston içinde, Neoliberalism: A critical reader (s. 9-19). London: Pluto Press.

Eijffinger, S. C. ve de Haan, J. (1996). The political economy of central bank independence. Princeton, USA: Princeton University.

Evans, P. (1997). The eclipse of the state? Reflections on stateness in an era of globalization. World Politics, 50(1), 62-87. doi: 10.1017/S0043887100014726.

Evre, B. (2015), Neo-liberalizmin teorik açmazları ve pratik sonuçları: bir paradigma krizi, Amme İdaresi Dergisi, 48(4), 1-18.

Fairclough, N. (2001). Critical Discourse Analysis as a Method in Social Scientific Research. R. Wodak veM. Meyer içinde, Methods of Critical Discourse Analysis (s. 121-138). London: Sage.

Fairclough, N. (2002). Language in new capitalism. DiscourseぬSociety, 13(2), 163-166. doi: $10.1177 / 0957926502013002404$.

Fairclough, N. (2003). Analysing Discourse: Textual Analysis for Social Research. London: Routledge.

Fairclough, N. (2005). Neo-liberalism -a discourse- analytical perspective. Polifonia, 10, 21-52.

Fairclough, N. (2010). Critical discourse analysis: The study of language. London: Routledge.

Fairclough, N. (2013). Critical discourse analysis and critical policy studies. Critical Policy Studies, 7(2), 177197. doi: 10.1080/19460171.2013.798239.

Forder, J. (2004). Central bank independence: Economic theory, evidence and political legitimacy. P. Arestis veM. Sawyer içinde, The rise of the market: Critical Essays on the political economy of neo-liberalism (s. 145-180). Massachusetts, USA: Edward Elgar Publishing.

Freeman, J. R. (2002). Competing commitments: Technocracy and democracy in the design of monetary institutions. International Organization, 56(4), 889-910. doi: 10.1162/002081802760403810.

Friedman, M. (1963). Capitalism and freedom. Chicago: University of Chicago Press.

Galbraith, J. K. (1971). The new industrial state. Boston: Houghton Mifflin Co.

Galbraith, J. K. veSalinger, N. (2002). Ekonomi üzerine hemen herşey. (Ö. Ozankaya, Çev.) İstanbul, Türkiye: Cem Yayınevi.

Garrett, G. (1995). Capital mobility, trade and the domestic policy of economic policy. International Organization, 49(4), 657-687. doi: 10.1017/S0020818300028472.

Garrett, G. (1998). Global market and national politics: Collision course or virtous circle? International Organization, 52(5), 787-824. doi: 10.1162/002081898550752. 
Garrett, G. ve Lange, P. (1995). Internationalization, institutions and political change. International Organization, 49(4), 627-655. doi: 10.1017/S0020818300028460.

Gaus, D., Landwehr, C. ve Scmalz-Bruns, R. (2020). Defending democracy against technocracy and populism: Deliberative democracy's strengths and challenges. Constellations, 27, 335-347. doi: 10.1111/14678675.12529.

Gellner, E. (1992). Uluslar ve ulusçuluk. (B. E. Behar veG. G. Özdoğan, Çev.) İstanbul, Türkiye: İnsan Yayınları.

Goodfriend, M. (2007). How the World Achieved on Monetary Policy. Journal of Economic Perspectives, 21(4), 47-68. doi: 10.1257/jep.21.4.47

Gökgöz, G. (2013). Paranın toplumsan yeniden üretimi: Merkez bankası iletişim politikaları. Ankara: NotaBene Yayınları.

Grilli, V., Masciandaro, D. ve Tabellini, G. (1991). Political and monetary institutions and public financial policies in the industrial countries. Economic Policy, 6(13), 341-392. doi: 10.2307/1344630.

Habermas, J. (2015). The lure of technocracy. (C. Cronin, Çev.) Cambridge, UK: Polity Press.

Haggard, S. ve Kaufmann, R. R. (1995). The political economy of transitions. Princeton: Princeton University Press.

Haggard, S. ve Webb, S. B. (1993). What do we know about the political economy of economic policy reform? The World Bank Research Observer, 8(2), 143-168. Erişim adresi: https://www.jstor.org/stable/3986530.

Hall, P. A. (2010). The political origins of our economic discontents: Contemporary adjustment problems in historical perspectives. Conference on politics in the new hard times in honor of Peter Gourevitch. San Diego: University of California. scholar.harvard.edu/hall/files/gourevitch.pdf (Erişim Tarihi: 04.03.2021).

Harvey, D. (2015). Neoliberalizmin kısa tarihi. (A. Onocak, Çev.) İstanbul, Türkiye: Sel Yayıncılık.

Hibbs, D. (1977). Political parties and macroeconomic policy. American Political Science Review, 71(4), 14671487. doi: $10.2307 / 1961490$.

Keefer, P. ve Stasavage, D. (2002). Checks and balances, private information and the credibility of monetary commitments. International Organization, 56(4), 751-774. doi: 10.1162/002081802760403766.

Keyder, Ç. (2009). Türkiye'de devlet ve sinıflar. İstanbul: İletişim Yayınları.

Kiely, R. (2107). From authoritarian liberalism to economic technocracy: Neoliberalism, politics and dedemocratization. Critical Sociology, 43(4-5), 725-745. doi: 10.1177/0896920516668386.

Klomp, J. ve de Haan, J. (2010). Do central bank reforms affect the term in office of central bank governance. Economic Letters, 106(3), 219-222. doi: 10.1016/j.econlet.2009.12.004.

Kuhn, T. S. (2008). Bilimsel devrimlerin yapısı. (N. Kuyaş, Çev.) İstanbul: Kırmızı Yayınları.

Kydland, F. E. ve Prescott, E. C. (1977). Rules rather than discretion: The inconsistency of optimal plans. The Journal of Political Economy, 85(3), 479-492. Erişim adresi: https://www.jstor.org/stable/1830193.

Locke, J. (2000). İnsanın anlama yetisi üzerine bir deneme. (M. D. Topçu, Çev.) Ankara: Öteki Yayınevi. 
Lohmann, S. (1992). Optimal credibility in monetary policy: Credibility versus flexibility. American Economic Review, 82(1), 273-286. Erişim adresi: https://www.jstor.org/stable/2117615.

Lohmann, S. (1998). Federalism and central bank independence: The politics of German monetary policy. World Politics, 50(3), 401-446. doi: 10.1017/S0043887100012867.

Masciandaro, D. ve Romelli, D. (2016). From silence to voice: Monetary policy, central bank governance and communication. Baffi Carefin Centre Research Paper No: 2016-27.

Masciandaro, D. ve Romelli, D. (2018). Central bankers and supervisors: Do crises matter? European Journal of Political Economy, 52, 120-140. doi: 10.1016/j.ejpoleco.2017.05.005.

Maxfield, S. (1997). Gatekeepers of growth: The international political economy of central banking in developing countries. Priceton, UK: Princeton University Press.

McCarthy, R. (1978). The ciritical theory of Jürgen Habermas. Boston: MIT Press.

McNamara, K. R. (2002). Rational fictions, central bank indepenence and the social logic of delegation. West European Politics, 25(1), 45-76. doi: 10.1080/713601585.

McNamara, K. R. (2008). A rivalry in the making? The euro and international money power. Review of International Political Economy, 15(3), 439-459. doi: 10.1080/09692290801931347.

Meyer, J. W., Boli, J., Thomas, G. M. ve Ramirez, F. O. (1997). World society and the nation state. American Journal of Sociology, 103(1), 144-181. doi: 10.1086/231174.

MHP (2021). Hakkında. Erişim adresi: https://www.mhp.org.tr

Mundell, R. A. (1962). The appropriate use of monetary fiscal policy for internal and external stability. International Monetary Fund, 9(1), 70-79. doi: 10.2307/3866082.

Mundell, R. A. (1963). Capital mobility and stabilization under fixed and flexible exchange rates. The Canadian Journal of Economics and Political Science, 29(4), 475-485. doi: 10.2307/139336.

Mundell, R. A. (1964). A reply: Capital mobility and size. The Canadian Journal of Economics and Political Science, 30(3), 421-431. doi: 10.2307/139708.

Muth, J. (1961). Rational expectations and the theory of price movements. Econometrica, 29(3), 315-335. doi: $10.2307 / 1909635$.

Nordhaus, W. N. (1975). The political business cycle. The Review of Economic Studies, 42(2), 169-190. doi: $10.2307 / 2296528$.

Pamuk, Ş. (2004). Karşılaştırmalı Açıdan Türkiye'de İktisadi Büyüme 1880-2000. A. H. Köse, F. Şenses, ve E. Yeldan (Ed.), İktisat Üzerine Yazılar I Küresel Düzen: Birikim, Devlet ve Sinıflar Korkut Boratav'a Armağan, (s. 383-398). İstanbul: İletişim Yayınları.

Polanyi, K. (2006). Büyük dönüşüm çağımızın siyasal ve ekonomik kökenleri. (A. Buğra, Çev.) İstanbul, Türkiye: İletişim Yayınları.

Putnam, R. D. (1977). Elite transformation in advanced industrial societies: An emprical assessment of the theory of technocracy. Comporative Political Studies, 10(3), 383-412. doi: 10.1177/001041407701000305.

Rodrik, D. (2011). The globalization paradox: Why global markets, states and democracy can't coexist. Oxford, UK: Oxford Univ. Press. 
Rogoff, K. (1985). The optimal degree of commitment to an intermediate monetary target. Quarterly Journal of Economics, 100(4), 1169-1190. doi: 10.2307/1885679.

Sanchez-Cuenca, I. (2017). From a deficit of democracy to a technocratic order: The postcrisis debate on Europe. Annual Review of Political Science, 20(1), 351-369. doi: 10.1146/annurev-polisci-061915110623.

Sargent, T. ve Wallace, N. (1975). Rational expectations, the optimal monetary instrument and the optimal money supply rule. Journal of Political Economy, 83(2), 241-254. Erişim adresi: https://www.jstor.org/stable/1830921.

Simmel, G. (2011). The philosophy of money. Cornwall: Routledge.

Simmons, B. A., Dobbin, F. ve Garrett, G. (2006). Introduction: The international diffusion of liberalism. International Organization, 60(4), 781-810. doi: 10.1017/S0020818306060267.

Sönmez, Ü. (2011). Piysanın idaresi, neoliberalizm ve bağımsız düzenleyici kurumların anatomisi. İstanbul, Türkiye: İletişim Yayınları.

Tavlas, G. S. (1993). The new theory of optimum currency areas. The World Economy, 16(6), 663-685. doi: 10.1111/j.1467-9701.1993.tb00189.x.

TCMB (2021). Türkiye Cumhuriyet Merkez Bankası ve Bağımsızlık. Erişim adresi: https:/www.tcmb.gov.tr/wps/wcm/connect/tr/tcmb+tr/main+menu/banka+hakkinda/tarihce

Wallerstein, I. (2005). Dünya sistemleri analizi: Bir giriş. (E. Abadoğlu veN. Ersoy, Çev.) İstanbul, Türkiye: Aram Yayıncilık.

Yenal, O. (2003). Cumhuriyetin İktisat Tarihi. İstanbul: Homer Kitabevi.

Yeldan, E. (2013). Küreselleşme Sürecinde Türkiye Ekonomisi Bölüşüm, Birikim ve Büyüme. İstanbul: İletişim Yayınları. 


\section{Extended Abstract}

\section{Purpose}

This study is aimed to explain how political parties complied with neoliberal ideas in Turkey. In this context central bank independence is examined in terms of support of political parties in the context of adaptation to neoliberalism and technocracy in Turkey. Due to these considerations, the following questions are sought in the study: "Why political parties in Turkey have preferred central bank independence, which means loss of control of monetary policy when they came to power?", "What kind of discourses have used by political parties to convince their voters?", "Do such preferences have a relationship between neoliberal ideas and technocracy that includes expertise and knowledge?", "Is there any difference among political parties in supporting central bank independence?”.

\section{Design and Methodology}

In order to answer these questions, Justice and Development Party (JDP), Republican People's Party (RPP), Nationalist Movement Party (NMP), Democratic Left Party (DLP), Motherland Party (MP), and Virtue Party (VP) were selected as political parties which represent right-wing, left-wing, nationalist, and Islamist ideologies in Turkey. The election statements of these parties were analyzed as analysis material. The purposive sampling method has used the selection of these political parties and the election statements which political parties published. These reports were analyzed by Fairclough's (2001, 2002, 2003, 2005, 2010) critical discourse analysis method. In the study, the election declarations of the parties participating in the 1999 and 2002 elections were analyzed.

\section{Findings}

The findings show that all these parties directly or indirectly defend and support the central bank's independence by justifying its compliance with the neoliberal system, political instabilities, reducing public deficits, preventing the central bank from supporting public spending and price stability. Since the 90s, the political and economic instability experienced in Turkey has accelerated the process of adaptation to the world economy and neo-liberal ideology. Therefore, although the political parties discussed in the study have centerright, center-left, nationalist, and Islamist ideologies, they found the solution of economic problems compatible with the neoliberal ideology that dominates the world. All parties whose election statements are examined contain statements supporting the independence of the central bank in their election statements for the 1999 general elections. Therefore, it is seen that all parties prepared their voters for the conditions of this program before the Transition to Strong Economy Program, which was implemented in 2001 and included neoliberal institutional transformations. In the general elections held in 2002, the coalition partner parties (DLP, NMP, and MP), which implemented the program for the transition to a strong economy, entered the elections for the first time and established a single-party government (JDP) and the main opposition party (RPP) have declared a commitment to maintaining legal independence of the central bank. Thus, all of them supported the abandonment of the management of monetary policy to technocracy around the neutral money understanding, which is the basic approach of neoliberalism. As a result, political parties have now tended to derive their legitimacy from technocracy in their economic policies.

\section{Research Limitations}

The limitation of this study is the election statements of the parties that were in power and served as the main opposition before and after the program of transition to a strong economy that fully adapted to the neoliberal structure in Turkey. Because of this purpose Justice and Development Party (JDP), Republican People's Party 
(RPP), Nationalist Movement Party (NMP), Democratic Left Party (DLP), Motherland Party (MP), and Virtue Party (VP) were selected as political parties which represent right-wing, left-wing, nationalist, and Islamist ideologies in Turkey. The fact that the election statements of these political parties are taken into account is due to the fact that these parties reflect the main political trends.

\section{Implications}

Neoliberalism in Turkey supports the abandonment of the monetary policy management to the technocracy around the neutral money understanding. Therefore, political parties tended to obtain their legitimacy from technocracy in their economic policies. This circumstance causes political parties in Turkey to put their own ideologies in the background in order to adapt to the neoliberal ideology. This causes social problems to be pushed into the background in monetary policies. Thus, Turkey makes the motto "multi-party, one ideology" dominant in its political life and economic policies. This situation leads to the transformation of each political party into a neoliberal political organ. Under the rule of technocracy, monetary policy has gained a neutral identity in the face of social problems in the context of scientific and expertise principles.

\section{Originality Value}

This study analyzes the interaction between technocracy and politics, strengthened by neoliberalism, by using the election manifestos of political parties before and after the Transition to a Strong Economy Program implemented in Turkey. In this study, the gap in the literature was filled by using the critical discourse analysis method in order to evaluate the approaches of political parties. This analysis offers original value in terms of determining how parties with different ideologies adopt an approach to alter the dominant neoliberal structure in Turkey. Consequently, it is possible to emphasize the neoliberalism transforms the political parties to neoliberal institutions.

Araştırmacı Katkısı: Ragıp YILMAZ (\%50), Oytun MEÇİK (\%50). 